\title{
Framing and Identity: How Mainland and Taiwan Media Represent Terrorist Attacks in China?
}

\author{
Yan Wang $^{1 *}$ \\ ${ }^{1}$ College of Humanity, 310023 Zhejiang University of Technology, Hangzhou
}

\begin{abstract}
Loss of identity is a leading cause of terrorism and a common bewilderment of Mainland China and Taiwan. Cutting into the research by the news representation of Chinese terrorism incidents, this paper discusses a special identity issue in a special identity history. This paper adopts mixed methods, which are constructed by content analysis, framing discourses and frequency statistics. 111 pieces of related news are selected and doubly-coded into both "identity package" and "news framing". The results show that the news representations inter-connect with the coexisting identity and confrontation between Mainland China and Taiwan.
\end{abstract}

\section{Introduction}

The occurrence of terrorism incidents usually reinforces the complexity of the interaction between media and society. What media frame agrees with or disagrees with closely relates to what the media finally presents. Likewise, terrorism is also the outcome of construction. The nature of terrorist incidents rests on a country system's recognition of the relationship between itself and the violence. News representation of terrorism incidents and its effect of publicity are inseparable from media's and audiences' recognitions on target countries respectively. Therefore, media representation of terrorism deserves dissecting and the relation between identity and terrorism deserves questioning. The pursuit of identity, a historical problem, also disturbs Mainland China and Taiwan. ---- Where do Chinese terrorists come from? How is terrorism represented on news? And how does media's stance on ethnic countries influence the news representation of terrorism incidents? How does news representation in different Chinese-speaking regions construct and attribute terrorism? From which perspective can we view the questions, for instance, "who are we", "who is the other", and "who are terrorists?" Taking mainland China and Taiwan's media representation of Chinese terrorism incidents as its core, this study tends to probe into the relation between terrorism and identity.

\footnotetext{
* Corresponding author: talktowangyan@gmail.com
} 


\section{Method}

This study employs a mixture of method. Firstly, we select various representative media of different styles from both Mainland and Taiwan. (a) People's Daily and the People's Daily Overseas Edition are chosen from all the central-level media of Mainland China so internally and externally, but also reflect the distinct identity preference of ethnic Chinese people inside and outside China. (b) Xinjiang Daily, Kunming Daily and Hangzhou Daily are selected as representative provincial media, because of their geological closeness towards the incidents. (c) China Times and Liberty Times are collected in this study as Taiwan local media. The former one is famous for its conservatism while the later one for its strong appeal for Taiwan nationalism, "Taiwan first" and "Taiwan priority", as a result the combination of these two media can offer a diverse opinions of Taiwan society.

Secondly, according to the survey of KCIS, systematically sampled from all the 18 terrorism incidents happened in Mainland China in 2014 (http://www.kcis.cn/8440) in chronological order, taking a determined terrorism incident every three attacks, there appear all together six terrorist attack incidents. Taking as analytic targets the related news covered within three days right after the incidents happen. The sample totaled 111 news texts which were then coded and registered.

Thirdly, according to the preliminary observation before coding, the news contents can be categorized to nine news-coding categories: reporting date, media, page distribution, news narrating model, news source, event modality, event cause, news photograph and photography source.

At last, this study is dedicated to researching the relationship between the media framing and the national identity, so all news samples will be double-analyzed from both the respects of identity framing package and news framing.

\section{Findings}

The part of identity package refers to the theories "hegemonic domination"[1], "compromise discourse" [2] and "protest discourse" [3], which were developed by the author into three packages: "unconditional approval", "critical identity" and "critical disagreement". As the news framing part, the study reviews the contrasting framings employed by Chen [4], namely "critical \& disagree", "identity \& segregation", "propaganda \& mobilization", "compatriots \& sympathy", "critique \& governance", "violence \& Conspiracy" and "critique \& dialogue" (Table 1)

Table 1 Identity package and news framing of this study

\begin{tabular}{lll}
\hline Identity Package & News Framing & Main Idea \\
\hline $\begin{array}{l}\text { Unconditional } \\
\text { Approval }\end{array}$ & stability \& struggle & $\begin{array}{l}\text { Restoring social order, against violent } \\
\text { terrorism, stability is prior to } \\
\text { everything } \\
\text { The event's nature of terrorism } \\
\text { incidents, prevent separatism } \\
\text { Encourage people to throw oneself } \\
\text { into restoration } \\
\text { The security of the victim, the } \\
\text { perpetrator and other party involved } \\
\text { Improving governance, criticize the } \\
\text { existing ethnic policy } \\
\text { puspect that the authority withholds } \\
\text { information }\end{array}$ \\
critical & compatriots \& sympathy &
\end{tabular}


critique \& dialogue

Others
Unclassifiable Framing
Deny the terrorist nature of the incident, compare a wide range of news sources

\section{1 "Unconditional approval" package}

The media in Mainland China, all taking Xinhua News Agency, the official news agency of the Communist Party, as their source of news, have been presenting their unshakable loyalty by "unconditional approval". The scenes, murderers, victims, causes of the event and countermeasures of terrorist attacks are also shelved and obscured. The reaction to crises and the scale of reports of local media in Mainland China has slightly progressed compared with the time before, but generally they are still positioned as a loudspeaker, following the order of officials and demonstrating a high level of national identity. In the regard of constructing the national identity, the role that the national media play in the "stability \& struggle" and "identity \& segregation" framing is much more influential than local media who pay more attention to the "propaganda \& mobilization" framing.

\subsection{1 "Stability \& Struggle" Framing}

First, it is the preemption that sets the basic tone for public opinion through authoritative sources. On March $2^{\text {nd }}$, People's Daily and Xinjiang Daily published on their own front page the press release of Xinhua News Agency, Beijing, Xi Jinping's crucial instructions on the violent incident in Kunming Railway Station in Yunnan Province (People's Daily, 2014.3.2:1). The first paragraph directly offer us the plot (main incident), and the next three paragraphs inform us of the instructions and dispositions on this incident from Chairman Xi Jinping, Premier Li Keqiang and other related figures in Yunnan provincial party committee and government in sequence, showing the will and the determination of taking resolute and effective measures to solve this complicated problem.

Second, the news agencies strengthen the accusative cognition and crackdown based on the source's preference. Also, the opinion of their own commentator is attached on the same page. The critique of People's Daily, Punish Terrorism Crime, Secure Public Safety, puts the terrorist attack in the context of "preparing for the Two Sessions and getting ready for comprehensively deepening reform", accuses the terrorism of breaching peace and stability, urges " 1.3 billion people to be united to crack down violent crime", and finally summarizes "the terrorists' creating this bloody and horrible scene has woken up the justice and power in people's mind and strengthened people's conviction of defending social stability", and at the same time, "the party and the government has shown their solid determination to crack down violent terrorism, further boosting people's confidence of maintaining peace and harmony".

\subsection{2 "dentity \& segregation" framing}

Compared with People's Daily which mainly targets at domestic readers, People's Daily Overseas Edition targets at Chinese people who live in Taiwan, Hong Kong or other foreign countries where information system is more open and national identity is more complicated. Therefore, the latter one tends to adopt a strategy of gathering people who agree with China and separating people who disagree when covering news. It also frequently quotes international voices that are coincident with Chinese authorities in terms of attribution and crack down those sources that take an opposite point of view, thus creating the binary framing, "identity \& segregation", so as to establish a consensus. 
In the basic mode of secondary incidents of Kunming 301 incident, the debate over determining the nature of terrorism took place unexpectedly. The specific cause was that CNN used quotation marks on the word "terrorist" in related coverage and claimed wickedly that it was not the first time that a knife attack had taken place and incidents like this happened in campuses in 2010 and 2012, however, without any political relevance. In AP's coverage, the prefix "what the official called" was added to the word "terrorist". In addition, instead of "terrorists", New York Times, Washington Post, etc. called them "attackers" (People's Daily, 2014.3.3:3). As for the assault on policemen in Aksu on May 8, 2014, Xinjiang which hasn't been reported by People's Daily, People's Daily Overseas Edition directly quoted Xinhua News Agency, emphasizing the efficiency of police - killed one and arrested one, and the stable and normal situation in Aksu in just one simple and concise sentence (People's Daily Overseas Edition, 2014.5.8).

\subsection{3 "Propaganda \& Mobilization" Framing}

The "propaganda \& mobilization" framing is an important means of gaining national identity. By conducting propaganda and mobilizing, Mainland China urges all Chinese people to stick together and crack down terrorism and intensifies work in reconstruction and reassurance in the disaster areas. The most intensively-covered basic modes are "sincere condolence" in "Maola's Murder in Kashgar on July 30" and "medical treatment" in "Bus Arson in Hangzhou on July 5". In all basic modes of the coverage of "Kunming 301" incident from People's Daily, People's Daily Overseas Edition and Xinjiang Daily, the content concentrates mainly on medical treatment, sincere condolence, initiation of social security system, recovery of normal order and other plot (secondary incident) basic modes. The Maola's special identities as a social celebrity, a patriot and a religious leader make the incident more than influential, thus reach an effect of "propaganda \& mobilization". The Beijing authorities expressed condolence via the spokesman of State Administration for Religious Affairs of P.R.C. All 107 figures in the Xinjiang religious circle gather to hold a symposium on the 7.30 violent case, denouncing the violent and horrible act. There was no need for these leaders to show up and initiate the anti-violence and rescue systems due to the quick solution to the case, the Maola's death on the spot and no more casualties or site control.

\section{2 "Critical identity" package}

\subsection{1. "Compatriots \& Sympathy" Framing}

Contrary to the "plot" basic mode of media in Mainland China, China Times attaches much importance to describing the whole process of the incident, as well as the scene, the murders and the victims, fully demonstrating its deep sympathy for compatriots in Mainland China. The sympathy for victims comes first. Taiwan's China Times covered the "Kunming 301" incident at large, including 3 basic modes of incidents - the crime scene, the background analysis, and the responses in society (China Times, ROC 103.3.3:A1). Second, it mentioned the sympathy for the attackers. In "East Turkistan Terrorists Resort to Violence under the High Pressure of Maintaining Stability" (China Times, ROC 103.3.3: A3), it was pointed out that Uighurs in Xinjiang were under high pressure of maintaining stability. "With 32 measures of maintaining stability, a network of prevention and control with complicated structure was set up in Xinjiang. Urumqi alone was divided into more than 2500 regional units and the communities were monitored 24 hours a day. The fact that delitescent East Turkistan separatists "started to become violent and horrible" was closely 
related with the high pressure. Third, it agreed with the Beijing authorities, defining the incident as a terrorist attack. When Zhang Jinhua, a professor in the Graduate Institute of Journalism National Taiwan University, criticized that China Times' describing separatists in Xinjiang as terrorists was a partial quotation from Mainland China. Then China Times fought back with a question: "if this is not a terrorist attack, then what is?" (China Times, ROC 103.3.3: A3), further denounced that "Terrorism Acts are Intolerable" (China Times, ROC 103.3.4: A15), and reclaimed its position through a commentary from a civil servant "Unconditional Hatred of Separatists" (China Times, ROC 103.3.4: A14). In response to CNN's adding quotation marks to the word "terrorists", China Times published "CNN' double standards on "terrorists" and denounced that "the US wanted to separate our China" (China Times, ROC 103.3.4: A14). The phrase "our China" reflected a sympathetic emotion rooted from the close relationship.

\subsection{2. "Critique \& Governance" Framing}

First, it didn't quote any source from media in Mainland China; instead, it sent its own reporters to conduct an interview. The photos of the crime scene also take a major part, mostly quoted from the AP, the AFP and other foreign media. Second, it didn't quite agree with the Beijing authorities who called the attackers "terrorists" before confirmation and "Separatists in Xinjiang" or "Terrorists in Xinjiang" after confirmation. China Times quoted the official microblog of Kashgar's Communist Party Propaganda Office, justifying that not all the people in Xinjiang participated in the terrorist attack and it was more suitable to call the terrorists "East Turkistan Separatists". Third, China Times considered it as merely a fight between Uighurs in Urumqi and Han People, neither an incident caused by East Turkistan Separatists, nor a terrorist attack, which was different from the definition that the Beijing authorities had done to the July $5^{\text {th }}$ incident in 2009 . To its surprise, the political leaders in Beijing changed the district secretary in Xinjiang for this reason and enhanced the "high pressure" control (China Times, ROC 103.3.3:A3).Fourth, it reflected on the high-pressure policies that the Beijing authorities had put on Xinjiang.

\section{3. “Critical Disagreement” Package}

Though they are both Taiwan local media, Liberty Times name in its reports the cross-strait mainland as "China". In its "international edition", it even reports "Kunming 301" incident from a foreign perspective. This shows a strong disapproval on national identity.

\subsection{1. "Violence \& conspiracy" framing}

First, underscore violence through representing the crime scene. Though Liberty Times and China Times have both covered the story of "the miserable throat-slit mother of one pseudonymous as Wang Yu", Liberty Times employed a calm and objective tone with little mention of subjective words, such as "lament" and "chocked", as China Times used in its reports. (Liberty Times, 2014.3.3 : A5) Second, the report <Kunming Bloodshed, Specialists: Unrelated with International Terrorist Organizations $>$ adopts purposefully vague sources to create a conspiracy theory saying the top of CCP refuse to react. As the following citation from the report shows: "According to an informed source, some major general level PLA officers have been informed to keep indoors one or two hours before the incident, because 'the perpetrators are going to kill'." (Liberty Times, 2014.3.5 : A10) 


\subsection{2. "Critique \& dialogue" framing}

First, critiques on ethnic policies. This report quoted the human rights lawyer saying though the indiscriminate-killing "terrorists should be reproached, the fuse of such bloodsheds is "China's brutal ethnic policy", so "the Chinese government should reflect on its failed ethnic policy". (Liberty Times, 2014.3.3 : A5)Second, critiques on the Chinese government's lack of counter-terrorism ability and media's lack of quality. Thus, Liberty Times penetrates deeper than China Times by attributing terrorism incidents to historical reasons. However, they both ascribe terrorism incidents happened in China to observer's internal attribution not the actor's external attribution.Fourth, build a stage for dialog between Mainland China media and western media. Before quoted by Liberty Times, the Mainland China media can only use China Daily and its Overseas Edition to megaphone to western media for their "putting quotation marks on terrorists". Meanwhile, the named western media also appear as sources on Liberty Times. As a result, the two contesting groups of media meet and share the same status of Third-party sources on Liberty Times.

\section{Conclusion}

This study focuses on the news representation of terrorism incidents on both side of the Taiwan-Strait attempting to explore the relationships between terrorism, identity and media. The three major innovations are as followed:

First, the thesis detects that there is no fundamental improvement in the stalemate across the Taiwan Straits as well as the polarization of identity within Taiwan, which is manifested in the following aspects. (1) The confrontation between Mainland and Taiwan is embodied in an identity package, including "unconditional approval" (hegemonic domination), "critical identity" (compromise discourse) and "critical disagreement" (protest discourse). (2) There exist internal and external differences in the news reports on terrorism incidents. With the strategy of "one country, two faces", the separation and formation of identity are effectively prevented. (3) Though both taking a critical stance, China Times (Taiwan) and Liberty Times (Taiwan) are opposed in their identity.

Second, innovative research methods are adopted, which are constructed by "identity package" and "news framing". As a result, it might cause weak exclusiveness of the categorization, coding difficulty and low reliability and validity, finally leading to difficulties and limitations of the study. Therefore, the paper comes up with the following solutions. (1) By enhancing the integration of literature review and research perspectives, the paper refers to the solutions to some similar problems. (2) The test of mutual trust is expanded before the content analysis and the design of coding table is constantly optimized.

Another limitation of this study lies in its failure to carry out deep conceptualization and operationalization of "identity". The research of identity is quite complicated for it involves the fields of psychology, sociology, politics, etc. The study also fails to carry out an equivalent conversion among "the identity of news texts", "individual identity" and "collective identity". Besides, this paper seems to take advantage of reductionism by equating identity package with regional identity. Consequently, future researches can be done to study the identity of the audience for the news reports on Chinese terrorism incidents, and then serve as triangular cross-validation of my conclusions.

\section{References}

1. A. Gramsci, Selections from the Prison Notebooks, ed. and trans. Quintin Hoare and Geoffrey Nowell Smith. New York: International. (1971) 
2. S. Hall, The West and the Rest: Discourse and power. The Indigenous Experience: Global Perspectives, 165-173. (1992)

3. S. Hall, Cultural studies: Two paradigms. (1986)

4. H. M. Chen. Framing and Attribution: a Comparative Study of the Reports about the Urumqi July 5 Riot, J.Commun 1 : 71-77. (2010) 